\title{
EFEKTIVITAS PENEGAKAN HUKUM TERHADAP TINDAK PIDANA KORUPSI SECARA MASSAL ANGGOTA LEGISLATIF DAERAH
}

\author{
oleh: \\ Diliya Mariam Rinjani
}

\begin{abstract}
ABSTRAK
Efektivitas penegakan hukum tindak pidana korupsi yang dilakukan oleh anggota legistatif daerah perlu dikaji lebih lanjut, didasarkan pada maraknya kasus korupsi yang menjerat anggota legislatif di beberapa daerah di Indonesia yang dilakukan secara massal atau bersama-sama. Upaya pemberantasan korupsi harus menjadi komitmen bersama dan menjadi prioritas utama instrumen penegak hukum di daerah. Peran penegak hukum yaitu Kepolisian, Kejaksaan, Pengadilan dan KPK khususnya sangat dibutuhkan demi terselenggaranya pemerintahan daerah yang bersih dari praktik korupsi. Berdasarkan hal tersebut timbul identifikasi masalah yaitu: Bagaimana efektivitas penegakan hukum tindak pidana korupsi yang dilakukan secara massal oleh anggota legislatif daerah? dan Apakah hambatan penegakan hukum tindak pidana korupsi di Indonesia? Metode penelitian yang digunakan dalam tesis ini berupa metode penelitian yuridis normatif, spesifikasi penelitian bersifat deskriptif analitis yaitu uraian yang menggambarkan dan menganalisis permasalahan berdasarkan peraturan perundang-undangan yang berlaku. Metode pendekatan yang digunakan dalam penelitian ini adalah metode pendekatan yuridis normatif yaitu mengkaji data, tahap penelitian menggunakan studi kepustakaan dan penelitian lapangan, teknik pengumpulan data difokuskan dengan studi kepustakaan dan penelitan lapangan, alat pengumpul data dengan studi kepustakaan dan analisis data menggunakan yuridis kualitatif. Hasil dari pembahasan penelitian ini menunjukan bahwa efektifitas penegakan hukum tindak pidana korupsi yang dilakukan anggota legislatif daerah belum cukup efektif dikarenakan sumber utama tindak pidana korupsi yang dilakukan oleh anggota legislatif daerah tidak dapat dilepaskan dari terlibatnya pejabat eksekutif di daerah, kemudian penanganan Kasus Korupsi Daerah oleh elemen penegak hukum diantaranya kepolisian, kejaksaan, KPK dan pengadilan mengalami berbagai kendala dan hambatan khususnya yang menjadi sorotan saat ini adalah terkait dengan revisi Undang-Undang Komisi Pemberantasan Korupsi yang menuai pro dan kontra.
\end{abstract}

Kata Kunci: Korupsi, Massal, Anggota Legislatif Daerah

\section{PENDAHULUAN}

Korupsi adalah tindakan seseorang ataupun kelompok yang menyalahgunakan kepercayaan dalam suatu organisasi swasta maupun pemerintah untuk mendapatkan keuntungan sendiri. Menurut Undang-Undang Republik Indonesia Nomor 31 Tahun 1999 tentang Pemberantasan Tindak Pidana Korupsi mengartikan bahwa, "Korupsi adalah tindakan yang dilakukan setiap orang yang melawan hukum, perbuatannya memperkaya diri sendiri yang menguntungkan diri sendiri, orang lain, atau korporasi, menyalahgunakan wewenang yang dimiliki maupun kesempatan atau sarana yang ada karena jabatan yang merugikan keuangan negara atau perekonomian negara".

Tindak pidana korupsi terkait dengann berbagai kompleksitas masalah, antara lain masalah moral atau sikap mental, masalah pola hidup, budaya, dan lingkungan sosial, masalah kebutuhan atau tuntutan ekonomi, kesenjangan sosial ekonomi, serta masalah struktur atau sistem ekonomi, masalah sistem atau budaya politik, serta masalah mekanisme pembangunan 
dan lemahnya birokrasi atau prosedur administrasi (termasuk sistem pengawasan) di bidang keuangan dan pelayanan publik. ${ }^{1)}$

Korupsi menjadi penyakit yang sangat berdampak pada pembangunan, tatanan sosial dan juga politik sehingga perlu ada perhatian dan penanganan secara khusus. Korupsi mempunyai ciri-ciri atau karakterisitik sebagai kejahatan yang tidak mengandung kekerasan dengan melibatkan tipu daya muslihat, ketidakjujuran, pemanfaatan kedudukan untuk penyelewengan, penyuapan dan penyembunyian suatu kenyataan. Korupsi bukanlah sesuatu yang wajib untuk dilakukan oleh para pejabat atau pemegang kekusaan, korupsi bukanlah sesuatu yang tidak disengaja, juga bukan faktor kebetulan, melainkan suatu tingkah laku yang dilandasi niat atau motivasi tertentu.

Kasus korupsi pasti ada di setiap negara, namun dengan kadar yang berbeda-beda. Kasus korupsi biasanya terjadi sangat tinggi di negara-negara berkembang, termasuk Indonesia. Sekalipun telah dibentuk badan bernama Komisi Pemberantasan Korupsi (KPK), Dewasa ini tindak pidana korupsi di Indonesia semakin bertambah luas. Jika dulu tindak pidana korupsi terjadi di kalangan eksekutif dalam pengelolaan keuangan dan administrasi negara, maka sekarang meluas ke lembaga legislatif, terutama dalam pemilihan pemerintah daerah seperti Gubernur dan Bupati/Walikota. ${ }^{2}$ Tindak pidana korupsi semakin bertambah luas tanpa takut dan tanpa rasa mulai dari Sabang sampai Merauke. Maka perlu dikaji ulang penegakan hukum oleh para penegak hukumnya yaitu Polisi, Jaksa, Hakim, dan Pengacara, serta Petugas Lembaga Pemasyarakatan, para pemimpin Republik Indonesia, dulu dan sekarang yaitu Presiden, Menteri, Gubernur, dan para Penyelenggara Negara lainnya.

Pemberantasan tindak pidana korupsi menjadi salah satu agenda besar yang diusung Indonesia. Tindak pidana korupsi merupakan musuh bersama yang harus dilawan, karena tidak hanya merusak sendi-sendi bernegara, tindak pidana korupsi juga mengakibatkan terhambatnya upaya mewujudkan pemerintahan yang bersih dan demokratis (democratic and clean government). ${ }^{3)}$

Tahun 1999 diterbitkan Undang-Undang Republik Indonesia Nomor 31 Tahun 1999 tentang Pemberantasan Tindak Pidana Korupsi (UU PTPK). Dalam kurun waktu yang relatif singkat, UU PTPK telah menimbulkan perbedaan interpretasi dikalangan sarjana hukum. Di samping masalah ketentuan peralihan yang tidak secara eksplisit dicantumkan, masalah pembuktian terbalik kembali diperbincangkan. ${ }^{4)}$

Undang-Undang Pemberantasan Tindak Pidana Korupsi dianggap belum sempurna, oleh sebab itu untuk menyikapi hal tersebut pemerintah mempersiapkan sebuah Rancangan Undang-Undang (RUU) untuk mengamandemen Undang-Undang Republik Indonesia Nomor 31 Tahun 1999 tentang Pemberantasan Tindak Pidana Korupsi. Akhirnya pada 21 November 2001 terbitlah Undang-Undang Republik Indonesia Nomor 20 Tahun 2001 tentang Perubahan Atas Undang-Undang Nomor 31 Tahun 1999 tentang Pemberantasan Tindak Pidana Korupsi.

Berdasarkan ketentuan dalam Pasal 43 UU PTPK, Dewan Perwakilan Rakyat Republik Indonesia (DPR-RI) bersama dengan Presiden Republik Indonesia (Pemerintah) menerbitkan Undang-Undang Nomor 30 Tahun 2002 tentang Komisi Pemberantasan Tindak

1) Barda N, Arief, Masalah Penegakan Hukum dan Kebijakan Hukum Pidana dalam Penanggulangan Kejahatan, Kencana, Jakarta, 2014, hlm 136.

2) Andi Hamzah, Pemberantasan Korupsi Melalui Hukum Pidana Nasional dan Hukum Internasional, Rajawali Pers, Jakarta, 2015, hlm xiii.

3) Donal Fariz, Proyek Ambisius Pembentukan Pengadilan Tipikor, dalam Putih Hitam Pengadilan Khusus, Sekertariat Jenderal Mahkamah Konstitusi Republik Indonesia, Jakarta, 2013, hlm 213.

4) Elwi Danil, Korupsi : Konsep, Tindak Pidana, dan Pemberantasannya, Rajawali Pers, Jakarta, 2014, hlm 54. 
Pidana Korupsi (UU KPK). Komisi ini merupakan lembaga yang independen dengan tugas dan wewenang melakukan pemberantasan tindak pidana korupsi. ${ }^{5)}$

Profesional penegak hukum, memiliki tanggung jawab untuk menjaga agar setiap orang dapat merealisasikan kebebasannya dalam rangka mencapai tujuantujuan, namun tidak melebehi batas sehingga mengganggu kebebasan orang lain. Keadilan dalam konteks ini berarti kebebasan yang sama untuk memperjuangkan tujuan masing-masing orang. ${ }^{6}$

Komisi Pemberantasan Korupsi (KPK) dibentuk dengan tujuan meningkatkan daya guna dan hasil guna terhadap upaya pemberantasan tindak pidana korupsi. Posisi KPK yang menjadi sentral dari keseluruhan lembaga pemberantasan tindak pidana korupsi diperkuat dengan Pasal 1 angka 3 Undang-Undang Republik Indonesia Nomor 30 Tahun 2002 Tentang Komisi Pemberantasan Korupsi yang merumuskan pemberantasan tindak pidana korupsi sebagai serangkaian tindakan untuk mencegah dan memberantas tindak pidana korupsi melalui upaya koordinasi, supervisi, monitor, penyelidikan, penyidikan, penuntutan dan pemeriksaan di sidang pengadilan, dengan peran serta masyarakat berdasarkan peraturan perundang-undangan yang berlaku.

Dijelaskan pula dalam Pasal 6 Huruf a dan b Undang-Undang Republik Indonesia Nomor 30 Tahun 2002 Tentang Komisi Pemberantasan Korupsi yang menegaskan fungsi KPK sebagai trigger mechanism atau pendorong terhadap optimalisasi tugas dan fungsi Kepolisian dan Kejaksaan di bidang pemberantasan tindak pidana korupsi dengan melakukan koordinasi dan supervisi. Dalam kaitannya dengan koordinasi, KPK berwenang antara lain untuk mengkoordinasikan penyelidikan, penyidikan, dan penuntutan tindak pidana korupsi.

KPK telah banyak menangani kasus-kasus dalam tindak pidana korupsi, perkembangannyapun dari tahun ke tahun semakin baik KPK berhasil mengungkap kasuskasus tindak pidana korupsi yang sangat beragam, mulai dari korupsi yang terjadi di Pemerintah Pusat dan Pemerintah Daerah, Parlemen (DPR-RI dan DPRD), Lembaga Peradilan, Aparat Penegak Hukum, Badan Usaha Milik Negara (BUMN), sampai pada tindak pidana korupsi yang melibatkan pelaku usaha (Swasta). Selain tindak pidana korupsi di daerah dan di tingkat pusat, pengungkapan kasus-kasus tindak pidana korupsi juga terjadi dengan masif. Hampir tidak ada jabatan yang kebal terhadap penegakan hukum, deretan dugaan kasus tindak pidana korupsi yang telah diungkap diantaranya melibatkan pejabat negara, atau penyelenggara negara seperti Ketua Mahkamah Konstitusi, Menteri Pemuda dan Olahraga, Anggota DPR-RI, Gubernur, Bupati, dan lain sebagainya. Semakin baiknya kineja KPK dalam mengungkap perkara tindak pidana korupsi tidak berbanding lurus dengan berkurangnya pelaku tindak pidana korupsi. Tahun 2018 berdasarkan data statistik yang diambil dari website ACCH (Anti Coruption Clearing House), Per 31 Desember 2018, di tahun 2018 KPK melakukan penanganan tindak pidana korupsi dengan rincian: penyelidikan 164 perkara, penyidikan 199 perkara, penuntutan 151 perkara, inkracht 106 perkara, dan eksekusi 113 perkara. ${ }^{7)}$

Berdasarkan hasil pencarian berita dari situs detik.com hasil wawancara dengan Wakil Ketua KPK Saut Situmorang di gedung Penunjang KPK, menurutnya secara total, pada tahun 2018, KPK melakukan 157 kegiatan penyelidikan, 178 penyidikan, dan 128 kegiatan penuntutan, baik kasus baru maupun sisa penanganan perkara pada tahun sebelumnya. Selain itu, KPK mengeksekusi 102 putusan pengadilan yang telah berkekuatan hukum tetap. Dari total perkara yang ditangani KPK, 91 di antaranya melibatkan anggota DPR-RI atau DPRD. Ada juga 28 perkara yang melibatkan kepala daerah, baik yang aktif maupun mantan kepala daerah. Sementara, data penanganan perkara berdasarkan tingkat jabatan, mengungkapkan 2009, hlm 91.

5) C. S. T. Kansil et. al, Tindak Pidana dalam Undang-Undang Nasional, Jala Permata Aksara, Jakarta,

6 Dani Durahman, Penerapan Sanksi Bagi Penegak Hukum Penerima Suap Dalam Proses Peradilan Pidana, Jurnal Lex Specialist, Vol No 24 (2016) Universitas Batang Hari Jambi, hlm.51 
ada 91 perkara yang melibatkan anggota DPR-RI dan DPRD, 50 perkara melibatkan swasta serta 28 perkara melibatkan kepala daerah (29 kepala daerah aktif dan 2 mantan kepala daerah). Selain itu, terdapat 20 perkara lainnya yang melibatkan Pejabat Eselon I hingga IV. $\left.{ }^{7}\right)$

Perkara tindak pidana korupsi yang dilakukan secara massal baru-baru ini terungkap di beberapa wilayah di Indonesia dalam kurun waktu yang berdekatan diantaranya terjadi di Kota Malang, sebanyak 41 Orang dari total 45 Anggota DPRD Kota Malang terjerat dugaan kasus suap pembahasan APBD-P Pemerintah Kota Malang Tahun 2015 dengan Mantan Ketua DPRD Kota Malang, Moch Arief Wicaksono menjadi yang pertama kali divonis 5 tahun penjara berdasarka putusan Pengadilan Negeri Surabaya Nomor 16/Pid.SusTPK/2018/PN.Sby. Kemudian Perkara serupa terjadi di Provinsi Sumatera Utara, KPK menetapkan 38 Anggota dan mantan Anggota DPRD Sumatera Utara sebagai tersangka yang menerima suap dari Gatot Pujo Nugroho yang pada saat itu menjabat sebagai Gubernur Sumatera Utara terkait persetujuan laporan pertanggungjawaban Pemerintah Provinsi Sumatera Utara untuk Tahun Anggaran 2013-2014 oleh DPRD Sumatera Utara dan terkait pengesahan APBD tahun anggaran 2014-2015 dan penolakan penggunaan hak interplasi anggota DPRD Sumatera Utara pada tahun 2015. Gatot Pujo Nugroho sendiri dipidana penjara selama 3 tahun berdasarkan putusan Pengadilan Negeri Jakarta Pusat Nomor 161/Pid.Sus/TPK/2015/PN.Jkt.Pst.

Mengungkap tindak pidana, menemukan pelakunya dan menempat-kan pelaku di dalam penjara ternyata belum cukup efektif untuk menekan intensitas tindak pidana, dalam hal ini membiarkan pelaku tindak pidana tetap menguasai hasil dan instrumen tindak pidana akan memberikan peluang pada pelaku untuk kembali menggunakan instrumen tersebut bahkan mengembangkan tindak pidana yang pernah dilakukan. Permasalahan diatas melibatkan banyak individu yang secara bersama-sama melakukan tindak pidana, KUHP telah menjelaskan mengenai sebuah tindak pidana yang dilakukan secara bersama-sama atau ada turut serta campur tangan dari individu lain yaitu tercantum dalam Pasal 55 Kitab UndangUndang Hukum Pidana (KUHP) yang berbunyi :

“1) Dihukum sebagai orang yang melakukan peristiwa pidana:

1e. Orang yang melakukan, yang menyuruh melakukan, atau turut melakukan perbuatan itu;

2e. Orang yang dengan pemberian, perjanjian, salah memakai kekuasaan atau pengaruh, kekerasan, ancaman atau tipu daya atau dengan memberi kesempatan, daya upaya atau keterangan, sengaja membujuk untuk melakukan sesuatu perbuatan.

(2) Tentang orang-orang yang tersebut dalam sub $2 \mathrm{e}$ itu yang boleh dipertanggungjawabkan kepadanya hanyalah perbuatan yang dengan sengaja dibujuk oleh mereka itu, serta dengan akibatnya."

Fenomena tindak pidana korupsi yang terjadi di Indonesia yang melibatkan begitu banyak pejabat yang menduduki kursi anggota legislatif daerah menjadi sebuah permasalahan yang menarik untuk dianalisa apakah ada unsur keterpaksaan dalam melakukan tindak pidana korupsi hingga terlibat turut serta dalam melakukan tindak pidana atau memang ada niat dan kesadaran dalam diri pelaku.

\section{PEMBAHASAN}

\section{A. Kajian Terhadap Efektivitas Penegakan Hukum Tindak Pidana Korupsi Massal Anggota Legislatif Daerah}

Anatomi korupsi di daerah tidak bisa lagi dilihat terbatas dari kacamata 'lokal'. Untuk memenuhi 'pembiayaan politik' dalam proses pemilihan, seorang calon kepala daerah perlu mencari dukungan pembiayaan dari kelompok kepentingan dan pelaku politik di tingkat

\footnotetext{
${ }^{7}$ https://news.detik.com/berita/4350420/kpk-tangani-178-kasus-korupsi-di-2018-terbanyak-libatkanlegislatif diakses pada tanggal 4 April 2019 pukul 13.34 WIB.
} 
nasional. Pelaku di tingkat nasional memiliki kepentingan khusus dengan apa yang terjadi di tingkat lokal. Para pelaku bisnis di tingkat provinsi dan nasional memiliki kepentingan tersendiri untuk mendukung seorang calon yang pada gilirannya harus 'dibayar' ketika kelak ia menduduki posisi tersebut. Hal ini mengingat berdasarkan Undang-Undang Pemerintahan Daerah, seorang kepala daerah memiliki otoritas untuk menyetujui rencana investasi pelaku bisnis di daerahnya. Dalam konteks tersebutdapat disimpulkan bahwa sumber utama korupsi pemerintahan daerah sebagai berikut:

a. Manipulasi dana yang terjadi selama proses kampanye seorang Kepala Daerah dan 'donasi' yang dipakai untuk membayar partai politik atau anggota DPRD oleh calon kepala daerah yang melanggar peraturan mengenai bantuan dana bagi partai politik.

b. Manipulasi sumber pendanaan dari pusat kepada daerah, terutama dalam bentuk Dana Alokasi Umum (DAU), yang melibatkan pejabat dan anggota dewan di tingkat lokal dan kroni yang bekerja pada pemerintah pusat.

c. Biaya yang dikeluarkan oleh Kepala Daerah kepada kelompok kepentingan bisnis yang sebelumnya telah membiayai kampanye dan suap kepada anggota dewan dan partai politik pendukungnya.

\section{Peluang dan Modus Operandi Korupsi di Daerah}

Peluang korupsi lembaga DPRD salah satunya terjadi pada saat penyusunan anggaran APBD. Dalam penyusunan anggaran akan dibentuk panitia anggaran (panggar) yang unsurnya terdiri dari anggota DPRD dan pemerintah daerah. Modus operandinya antara lain sebagai berikut :

a. Memperbanyak atau memperbesar mata anggaran untuk tunjangan dan fasilitas bagi pimpinan dan anggota DPRD.

b. Menyalurkan dana APBD bagi Anggota DPRD melalui yayasan fiktif.

c. Melakukan perjalanan dinas fiktif.

Modus operandi korupsi DPRD sebagaimana diuraikan di atas selalu melibatkan pihak eksekutif seperti panitia anggaran dan kepala daerah yang menyetujui RAPBD (Rancangan Anggaran Pendapatan dan Belanja Daerah) yang memuat beragam mata anggaran bagi tunjangan dan pembiayaan anggota dewan. Oleh karena itu, pada hampir setiap laporan dugaan korupsi selalu mencantumkan pihak pemerintah daerah sebagai salah satu tersangka. Beberapa modus operandi korupsi pihak eksekutif pemerintah daerah antara lain :

a. Penggunaan sisa dana untuk dipertanggungjawabkan (UUDP) untuk kepentingan pribadi atau untuk kepentingan lain namun tanpa bisa dipertanggungjawabkan.

b. Penyimpangan terhadap mekanisme pengeluaran dan pemakaian dana kas daerah.

c. Pemindahbukuan dana kas daerah ke rekening pribadi kepala daerah.

d. Manipulasi terhadap jumlah sisa APBD.

e. Manipulasi dalam proses pengadaan.

2. Penanganan Kasus Korupsi Daerah dari Presfektif Penegak Hukum

a. Kepolisian

Terdapat sejumlah persoalan terkait kinerja Polri dalam penanganan kasus korupsi. Pertama, kasus korupsi kelas kakap cenderung di-peties-kan. Meskipun terdapat kasus yang berhasil dilimpahkan ke kejaksaan dan divonis bersalah oleh pengadilan namun saat ini massih banyak kasus korupsi kelas 'kakap' yang tidak jelas penanganannya atau 'dipetieskan', meskipun pihak Kepolisian telah menetapkan sejumlah tersangka.

b. Kejaksaan 
Sebagai lembaga yang paling awal dalam tahap proses hukum atas dugaan korupsi, tantangan terbesar bagi Kejaksaan adalah tingginya ekspektasi masyarakat yang diarahkan kepada lembaga ini. Proses dimulai dengan pemeriksaan saksi-saksi untuk merumuskan dugaan awal, penetapan tersangka, penyusunan dakwaan dan, setelah kasus masuk ke pengadilan, jaksa yang akan membuat draft tuntutan.

Respon kejaksaan bervariasi. Terdapat kasus dimana laporan diabaikan hingga adanya perintah dari Kejaksaan Tinggi atau Kejaksaan Agung, ada kasus di mana Kejaksaan langsung melakukan penyelidikan segera atau Jaksa menyatakan akan melakukan 'upaya edukasi' terlebih dahulu kepada institusi DPRD menyangkut dugaan korupsi yang mereka lakukan.

c. Komisi Pemberantasan Korupsi

Tidak dapat dipungkiri bahwa KPK telah menjadi garda terdepan pemberantasan korupsi. Meskipun dengan sejumlah catatan, kinerja yang ditunjukkan KPK setidaknya telah membangun kepercayaan publik tentang adanya lembaga penegak hukum yang secara serius melakukan pemberantasan korupsi. Kinerja KPK yang dapat dinilai sebagai catatan positif antara lain KPK sudah mulai menangani kasus korupsi di sektor yang dikehendaki masyarakat (korupsi politik, korupsi peradilan, korupsi perbankan) meskipun hasilnya belum maksimal.

KPK juga mulai memberikan perhatian untuk menangani korupsi daerah. Anggota DPR menjadi aktor yang paling banyak ditetapkan tersangka oleh KPK, dilanjutkan dengan aktor lainnya, berlatar belakang direktur swasta/pengusaha, pegawai kementrian/lembaga dan pejabat tinggi kementrian. Penindakan KPK juga melemah ketika berhadapan dengan pelaku yang memiliki latar belakang aparat penegak hukum, politisi, pengusaha besar,atau pihak lain yang mendapatkan dukungan politis serta menteri/anggota kabinet yang masih aktif. KPK juga belum optimal menggunakan Undang-undang Tindak Pidana Korupsi untuk menjerat pelaku korupsi.

Permaslahan di tubuh KPK baru-baru ini kembali muncul, DPR akhirnya resmi mengesahkan revisi Undang-Undang Nomor 30 Tahun 2002 tentang Komisi Pemberantasan Tindak Pidana Korupsi atau Undang-Undang KPK menjadi undangundang dalam sidang paripurna yang digelar pada tanggal 17 September 2019.

Pro dan kontra muncul di masyarakat. Bagi yang menentang, revisi tersebut dianggap sebagai upaya melemahkan KPK. Perlawanan tersebut juga berasal dari tubuh KPK sendiri. Wakil Ketua KPK Saut Situmorang menegaskan, pihaknya akan melawan segala upaya pelemahan KPK. Revisi UU KPK mendapat banyak kritik. DPR dituding ingin melemahkan Komisi Pemberantasan Korupsi (KPK).

d. Pengadilan

Sulit mempercayai keseriusan dan komitmen lembaga pengadilan untuk memberantas korupsi di negeri ini. Karena seperti pada tahun-tahun sebelumnya, lembaga pengadilan dalam hal ini, Pengadilan Umum hingga 2018 secara keseluruhan ternyata memberikan kontribusi besar terhadap makin melemahnya upaya pemberantasan korupsi. Meskipun Ketua Mahkamah Agung (MA) menyatakan akan berkomitmen dengan pemberantasan korupsi. Namun faktanya pengadilan umum memberikan perubahan siginifikan bagi dukungan terhadap agenda pemberantasan korupsi. Baik MA maupun Pengadilan Umum dibawahnya (Pengadilan Tinggi dan Pengadilan Negeri), kenyataaanya masih menjadi institusi yang berlaku ramah terhadap para pelaku korupsi. 


\section{Penegakan Hukum Tindak Pidana Korupsi di Daerah}

Keterikatan antara politik, uang, dan korupsi sepertinya sesuai dengan keadaan yang terjadi saat ini. Menurut hasil survei Gobal Corruption Barometer (GBC) yang diadakan oleh Transparency International Indonesia (TII) tahun 2017, lembaga terkorup di Indonesia adalah lembaga Dewan Perwakilan Rakyat (DPR) pada urutan pertama, disusul oleh lembaga Birokrasi di tempat kedua, kemudian Dewan Perwakilan Rakyat Daerah (DPRD) di peringkat ketiga. ${ }^{8)}$

Dari sisi kepala daerah, dari tahun 2004 sampai dengan tahun 2017, telah ada 313 (tiga ratus tiga belas) Kepala Daerah yang tersangkut kasus korupsi18, dan dari periode bulan Januari sampai dengan bulan Juli 2018, telah ada 19 (sembilan belas) kepala daerah yang ditetapkan sebagai tersangka oleh KPK karena terlibat korupsi. ${ }^{9)}$

Selanjutnya dari sisi anggota legislatif (DPR/DPRD), KPK menjelaskan telah lebih dari 145 (seratus empat puluh lima) orang anggota DPRD di seluruh Indonesia yang tersebar di 13 (tiga belas) provinsi yang diproses dalam kasus korupsi. Totalnya kalau ditambah antara DPRD dan DPR lebih dari 220 (dua ratus dua puluh) orang yang sudah diproses. ${ }^{10)}$

Melihat dari data di atas sungguh menjadi sesuatu yang sangat mengkhawatirkan keterkaitan antara politik, uang, dan korupsi. Bahkan sebanyak 41 (empat puluh satu) orang anggota DPRD Kota Malang ditetapkan sebagai tersangka tindak pidana korupsi secara massal dan 38 orang Anggota DPRD Provinsi Sumatera Utara ditetapkan sebagai tersangka.

Pada masa demokratisasi, korupsi dan money politics adalah dua hal yang bertalian. Pada umumnya sumber untuk mendapatkan dukungan politik yang dibangun oleh para politisi diperoleh melalui hasil korupsi. Artinya jika kelak seorang politisi berhasil memperoleh posisi politik, ia akan melakukan korupsi untuk menggantikan biaya yang telah digunakan untuk mencapai tujuan politiknya. ${ }^{11)}$

\section{B. Hambatan Penegakan Hukum Tindak Pidana Korupsi di Indonesia}

Upaya melakukan pemberantasan korupsi bukanlah hal yang mudah. Meskipun sudah dilakukan berbagai upaya untuk memberantas korupsi, tetapi masih terdapat beberapa hambatan dalam pemberantasan korupsi. Operasi tangkap tangan (OTT) sering dilakukan oleh KPK, tuntutan dan putusan yang dijatuhkan oleh penegak hukum juga sudah cukup keras, namun korupsi masih tetap saja dilakukan. Hambatan dalam pemberantasan korupsi dapat diklasifikasikan sebagai berikut:

a. Hambatan Struktural, yaitu hambatan yang bersumber dari praktik-praktik penyelenggaraan negara dan pemerintahan yang membuat penanganan tindak pidana korupsi tidak berjalan sebagaimana mestinya.

b. Hambatan Kultural, yaitu hambatan yang bersumber dari kebiasaan negatif yang berkembang di masyarakat. Yang termasuk dalam kelompok ini di antaranya: masih adanya "sikap sungkan" dan toleran di antara aparatur pemerintah yang dapat menghambat penanganan tindak pidana korupsi.

8) https://www.liputan6.com/bisnis/read/2884114/geser-polri-dpr-jadi-lembaga-terkorup-di-indonesia diakses pada tanggal 19 September 2019 pukul 00.50 WIB.

9) $\quad$ https://www.jawapos.com/nasional/hukum-kriminal/11/12/2017/mendagri-tahun-20042017-313kepala-daerah-tersangkut-kasus-korupsi diakses pada tanggal 19 September 2019 pukul 00.55 WIB.

10) https://nasional.kompas.com/read/2018/07/19/07554661/januari-juli-2018-19-kepala-daerahditetapkan-tersangka-oleh-kpk diakses pada tanggal 19 September 2019 pukul 00.58 WIB.

11) TB. Massa Djafar, Krisis Politik dan Proposisi Demokratisasi: Perubahan Politik Orde Baru ke Reormasi, Jakarta, Bumi Aksara, 2015, hlm 191. 
C. Hambatan Instrumental, yaitu hambatan yang bersumber dari kurangnya instrumen pendukung dalam bentuk peraturan perundang-undangan yang membuat penanganan tindak pidana korupsi tidak berjalan sebagaimana mestinya.

d. Hambatan Manajemen, yaitu hambatan yang bersumber dari diabaikannya atau tidak diterapkannya prinsip-prinsip manajemen yang baik (komitmen yang tinggi dilaksanakan secara adil, transparan dan akuntabel) yang membuat penanganan tindak pidana korupsi tidak berjalan sebagaimana mestinya.

\section{KESIMPULAN DAN SARAN}

\section{Kesimpulan}

Berdasarkan pembahasan diatas maka dapat ditarik kesimpulan sebagai berikut :

1. Efektivitas penegakan hukum tindak pidana korupsi yang dilakukan oleh anggota legislatif daerah belum cukup efektif dikarenakan sumber utama tindak pidana korupsi yang dilakukan oleh anggota legislatif daerah tidak dapat dilepaskan dari terlibatnya pejabat eksekutif di daerah terutama dalam hal penyusunan RAPBD (Rancangan Anggaran Pendapatan dan Belanja Daerah) yang memuat beragam mata anggaran bagi tunjangan dan pembiayaan anggota dewan, yang menjadi salah satu faktor terjadinya korupsi. Sebagaimana teori berlaku efektifnya sebuah hukum menurut Bustanul Arifin yaitu lembaga atau penegak hukum yang berwibawa dan dapat diandalkan, peraturan hukum yang jelas dan sistematis, kesadaran masyarakat yang tinggi maka perlu ada faktor pendukung lain yaitu tersedianya jumlah sumber daya manusia yang memadai demi memaksimalkan efektivitas penegakan hukum di daerah, dan juga peraturan hukum yang sudah jelas dan sistematis tersebut harus dipatuhi bukan dilemahkan.

2. Hambatan penegakan hukum di bidang tindak pidana korupsi dalam negeri ini masih lemah. Hal yang dapat disoroti adalah adanya upaya sistematis untuk melemahkan eksistensi dan peran lembaga antikorupsi, khususnya Komisi Pemberantasan Korupsi (KPK). Kemudian adanya tumpang tindih dan kurangnya kerja sama antar lembaga negara dalam upaya pemberantasan tindak pidana korupsi, baik oleh kepolisian, kejaksaan, dan KPK, dan adanya indikasi intervensi politik baik dari jajaran eksekutif maupun legislatif dalam kasus-kasus korupsi yang melibatkan pejabat publik atau partai politik tertentu, yang terakhir yaitu belum tumbuh dan berkembangnya budaya antikorupsi, baik di dalam tubuh birokrasi maupun masyarakat.

\section{Saran}

1. Maraknya kasus tindak pidana korupsi dalam tubuh legislatif daerah disebabkan oleh sistem politik yang berkembang di Negara Indonesia, dapat dikatakan bahwa korupsi yang terjadi didaerah merupakan sebuah korupsi politik. Maka saran penulis adalah sudah selayaknya terminologi korupsi politik diresmikan dengan menjadikannya sebagai delik khusus dalam undang-undang tindak pidana korupsi, entah sebagai delik yang memang benar-benar baru atau pun berupa klausul lanjutan dari delik yang dikualifisir atau diperberat karena keadaan tertentu yang menyertai perbuatan korupsi tersebut, sehingga nantinya kualifikasi korupsi politik benar-benar telah teradopsi menjadi tindakan yang menurut sesuatu rumusan undang-undang telah dinyatakan sebagai tindakan yang dapat dihukum, dan penegakan hukum terhadap tindak pidana korupsi bisa lebih efektif.

2. Meskipun pemberantasan korupsi menghadapi berbagai kendala, namun upaya pemberantasan korupsi harus terus-menerus dilakukan dengan melakukan berbagai perubahan dan perbaikan. Perbaikan dan perubahan tersebut antara lain terkait dengan lembaga yang menangani korupsi agar selalu kompak dan tidak sektoral, upaya-upaya 
pencegahan juga terus dilakukan, kualitas sumber daya manusia perlu ditingkatkan, kesejahteraan para penegak hukum menjadi prioritas.

\section{DAFTAR PUSTAKA}

\section{Buku}

Barda N, Arief, Masalah Penegakan Hukum dan Kebijakan Hukum Pidana dalam Penanggulangan Kejahatan, Kencana, Jakarta, 2014, hlm 136.

Andi Hamzah, Pemberantasan Korupsi Melalui Hukum Pidana Nasional dan Hukum Internasional, Rajawali Pers, Jakarta, 2015, hlm xiii.

Donal Fariz, Proyek Ambisius Pembentukan Pengadilan Tipikor, dalam Putih Hitam Pengadilan Khusus, Sekertariat Jenderal Mahkamah Konstitusi Republik Indonesia, Jakarta, 2013, hlm 213.

Elwi Danil, Korupsi : Konsep, Tindak Pidana, dan Pemberantasannya, Rajawali Pers, Jakarta, 2014, hlm 54.

C. S. T. Kansil et. al, Tindak Pidana dalam Undang-Undang Nasional, Jala Permata Aksara, Jakarta, 2009, hlm 91.

TB. Massa Djafar, Krisis Politik dan Proposisi Demokratisasi: Perubahan Politik Orde Baru ke Reormasi, Jakarta, Bumi Aksara, 2015, hlm 191.

\section{Peraturan Perundang-undangan}

Undang-Undang Nomor 31 Tahun 1999 tentang Pemberantasan Tindak Pidana Korupsi

Undang-Undang Nomor 20 Tahun 2001 tentang Perubahan Atas Undang-undang Nomor 31

Tahun 1999 tentang Pemberantasan Tindak Pidana Korupsi.

Undang-undang Nomor 30 Tahun 2002 tentang Komisi Pemberantasan Tindak Pidana Korupsi

Undang-Undang Nomor 2 Tahun 2002 tentang Kepolisian Negara Republik Indonesia

Undang-Undang Nomor 18 Tahun 2003 tentang Advokat

Undang-Undang Nomor 16 Tahun 2004 Tentang Kejaksaan

Undang-Undang Nomor 46 Tahun 2009 tentang Pengadilan Tindak Pidana Korupsi

Undang-Undang Nomor 48 Tahun 2009 tentang Kekuasaan Kehakiman

\section{Sumber Lainnya}

Dani Durahman, Penerapan Sanksi Bagi Penegak Hukum Penerima Suap Dalam Proses Peradilan Pidana, Jurnal Lex Specialist, Vol No 24 (2016) Universitas Batang Hari Jambi

https://acch.kpk.go.id/id/statistik/tindak-pidana-korupsi diakses pada tanggal 4 April 2019 pukul 13.29 WIB.

https://news.detik.com/berita/4350420/kpk-tangani-178-kasus-korupsi-di-2018-terbanyaklibatkan-legislatif diakses pada tanggal 4 April 2019 pukul 13.34 WIB.

https://www.liputan6.com/bisnis/read/2884114/geser-polri-dpr-jadi-lembaga-terkorup-diindonesia diakses pada tanggal 19 September 2019 pukul 00.50 WIB.

https://www.jawapos.com/nasional/hukum-kriminal/11/12/2017/mendagri-tahun-20042017313-kepala-daerah-tersangkut-kasus-korupsi diakses pada tanggal 19 September 2019 pukul 00.55 WIB.

https://nasional.kompas.com/read/2018/07/19/07554661/januari-juli-2018-19-kepala-daerahditetapkan-tersangka-oleh-kpk diakses pada tanggal 19 September 2019 pukul 00.58 WIB. 